\title{
MANAGING THE FINANCIAL RISKS AFFECTING CONSTRUCTION CONTRACTORS: IMPLEMENTING HEDGING IN SRI LANKA
}

\author{
Charith Kaushalya FERNANDO a, M. Reza HOSSEINI b , Edmundas Kazimieras ZAVADSKAS c,*, \\ B. A. K. S. PERERA a, Raufdeen RAMEEZDEEN ${ }^{d}$ \\ a Department of Building Economics, University of Moratuwa, Moratuwa, Western Province 10400, \\ Sri Lanka \\ $b$ School of Architecture and Built Environment, Deakin University, Locked Bag 20001, Geelong, Vic- \\ toria, 3220, Australia \\ ${ }^{c}$ Department of Construction Technology and Management, Vilnius Gediminas Technical University, \\ Sauletekio al. 11, LT-10223 Vilnius, Lithuania \\ d School of Natural and Built Environments, University of South Australia, Adelaide, South Australia \\ 5001, Australia
}

Received 1 February 2016; accepted 10 December 2016

\begin{abstract}
The aim of this study is to ascertain the major financial risks affecting construction contractors in Sri Lanka and to investigate the suitability of available hedging techniques as remedial solutions in managing such financial risks. To this end, the study identifies the most serious financial risks and the most commonplace hedging techniques to deal with the identified risks for Sri Lankan contractors through three unstructured interviews and a questionnaire survey administered among financial experts resulting in 33 duly completed responses. Analysis of the results is performed mainly using Analytic Hierarchy Process (AHP) methodology. As per the findings, the most serious financial risk affecting contractors was found to be associated with variations in material prices. The most commonplace hedging technique used by contractors to deal with the identified financial risks was 'forward contracts'. The study prioritises the hedging techniques with respect to their suitability for dealing with financial risks in form of an integrated model. This study provides an illuminating insight into financial risks and measures to mitigate them through implementing hedging techniques with a focus on construction contracting in Sri Lanka. The findings can be held up as examples for other developing countries suffering from similar issues.
\end{abstract}

KEYWORDS: Financial risk; Risk management; Hedging; Construction industry; Analytical hierarchy process; Sri Lanka

\section{INTRODUCTION}

The construction industry entails working in a dynamic, highly risky and challenging businesses environment (Iqbal et al. 2015). Projects in the construction sector are prone to more risk and uncertainty than any other sector (Zavadskas et al. 2010a). In such an environment, risks would influence every aspect of work and could obstruct the fulfilment of primary objectives (Perera et al. 2014). Consequently, the success of a construction project heavily relies on proper management of risks (Banaitienè et al. 2011). In this context, the management of financial risks should be par-

\footnotetext{
* Corresponding author. E-mail: edmundas.zavadskas@vgtu.lt
}

ticularly emphasised (Chen et al. 2012; Ginevičius, Podvezko 2006). According to Chen et al. (2010, 6510) "safeguarding against financial risk is a critical factor for a company's success. Such risks can often be serious enough to drive a construction company to distress or even bankruptcy". The severity of financial risks becomes doubly important for economies and markets in developing countries that face high levels of inflation and uncertainty (Battermann, Broll 2001). In many developing countries, financial shortcomings and cash flow problems have contributed to the general underdevelopment and underperformance of the construction industry (Ghoddousi, Hosseini 2012). 
In sharp contrast to the noticeable impacts of financial risks on contractors in developing countries, studies focusing on financial risks and strategies to deal with them are scarce (Iqbal et al. 2015). Besides, findings of studies on risk on construction projects conducted within developed economies are not necessarily applicable to the context of developing countries (Hosseini et al. 2016; Zhi 1995). That is because, "issues pertaining to projects risks are subjective and highly susceptible to the unique political, economic, environmental and sociocultural conditions of a country" (Perera et al. 2014: 3). As will be discussed, the emerging awareness of the necessity of proper management of financial distresses in the construction industry has motivated this study. The reason for choosing hedging among other available methods has been the proven abilities of hedging for managing risks associated with firm's finance and investment (Campello et al. 2011), particularly for project-based environments which are exposed to high levels of uncertainty (Ferguson et al. 2012). Hedging is a widely accepted technique that can be deployed to manage financial risks in a wide range of industries (Hammoudeh et al. 2010; Hofmann 2011) including the construction industry (Ling, Hoi 2006).

Knowledge on implementation of hedging to mitigate financial risks in the construction context is very limited. Nevertheless, hedging has become a topical matter in the Sri Lankan construction industry thanks to the controversial hedging agreement between Ceylon Petroleum Corporation and several banks. Added to this have been the financial issues faced by the construction industry due to a sudden surge of activity resulting from the Indian Ocean tsunami of 2004 (Ruddock et al. 2010). Furthermore, construction is the fourth largest sector within the national economy of Sri Lanka which contributes to 6-7\% of the Gross Domestics Product (GDP). The Sri Lankan construction industry plays a vital role in the national economy by generating $5-6 \%$ of employment (Ruddock et al. 2010). On top of that, financial aspects of constriction projects in Sri Lanka rely on Sri Lankan government (30-40\%) as well as foreign donors (Perera et al. 2014). The involved donor agencies provide financial assistance in various forms of funding on different projects (Yalegama et al. 2016). This adds another layer of complication to financial risks affecting Sri Lankan construction projects. Therefore, the primary objective here is twofold. The study aims at (1) identifying the major critical financial risks affecting contractors and
(2) investigating the potential of suitable hedging techniques to mitigate such risks within the Sri Lankan context.

The remainder of the paper is structured as follows. Presenting a theoretical perspective of financial risk management by hedging through a comprehensive review of literature comes next. This is followed by outlining the methods deployed in conducting the present study and justifying the details of the sampling techniques. An account of the results that came out of the analysis of the collected data is next. These results are interpreted in view of previous findings in the literature within the discussion section. The paper concludes with highlighting the novelty of the findings, acknowledging the limitations and suggesting future areas for investigation on the topic.

\section{FINANCIAL RISK MANAGEMENT BY HEDGING}

According to Iqbal et al. (2015: 66) "Risk is defined as exposure to loss/gain or the probability of occurrence of loss/gain multiplied by its respective magnitude". Risks in the construction context are generally deemed as occurrences that influence the primary objectives of a project, i.e. cost, time and quality (Dai et al. 2009). Moreover, the construction industry is exposed to a wide range of risks (Tah, Carr 2000). Construction projects are inherently delivered in dynamic environments, thus are affected by high uncertainty and influence of risks due to the accumulation of a wide range of interrelated factors (Zavadskas et al. 2015). Such serious risk and uncertainty could be attributed to factors such as considerable technological and organisational complexity (Shevchenko et al. 2008) and dynamic nature of construction projects (Hwang et al. 2013). This is exacerbated by the tight scheduling (Olawale, Sun 2010) and the immense size and volume of projects in the construction industry (Turskis et al. 2012). Even more, involvement of a large number of stakeholders in delivering projects further complicates the situation (Piyadasa, Hadikusumo 2014), because poor communication among the parties involved in delivering projects is a common risk in the construction industry (Ceric 2014). On top of that, the "very strong link" between construction organisations' operations and the performance of the economy and financial institutions is another source of risks for construction projects (Jiang, Liu 2015).

Financial risks represent the group of risks affecting construction firms in delivering project out- 
comes (Zou et al. 2007). As asserted by Iqbal et al. (2015) financial risks are among the most influential factors influencing construction projects. Some of the major financial risks of construction are unavailability of funds from the client, exchange rate fluctuations, inflation and financial default of a subcontractor (Perera et al. 2009). Financial risks are associated with the health of the contractors' cash flow (Akintoye, MacLeod 1997) and are affected by the effectiveness of decision-making procedures within construction organisations (Zavadskas et al. 2010b). Such risks are typically stemmed from the three main sources described below (Jorion 2009):

- Market risk - Losses due to movements in financial market prices or volatilities.

- Credit risk - Losses because counterparties may be unwilling or unable to deliver their contractual obligations.

- Operational risk - Losses resulting from failed or inadequate internal processes, systems, people or from external events.

Many researchers have referred to financial risks as critical for construction organisations (Hlaing et al. 2008; Ke et al. 2011). Fatemi and Glaum (2000) provided reasons for their evaluation of the criticality of financial risks while Sweis et al. (2008) reflected the consensus among contractors, consultants and owners regarding the detrimental effects of financial risks on the scheduling of construction projects. Failure to address financial risks properly will end up in contractors refusing to rectify defects, asking for extra payments, deliberately filing for bankruptcy and falling behind planned schedule just to mention a number of potential adverse consequences (Li et al. 2015).
Within the context of developing economies, Mansfield et al. (1994) named financial issues as the biggest problem affecting the Nigerian construction industry. In the case of Kuwait, financial failure was ranked by Kartam and Kartam (2001) as the highest among a host of other risk factors. In the same vein, contractors' lack of financial strength was one of the main challenges of Iran's construction industry (Ghoddousi, Hosseini 2012). Indeed financial risks are considered to be the most critical for Iranian contractors (Tadayon et al. 2012). Likewise, financial risks emerged as the major factors affecting the construction industry in Malaysia (Goh, Abdul-Rahman 2013) and Vietnam (Le-Hoai et al. 2008). Such evidence demonstrates that dealing with and overcoming financial risks is crucial for construction contractors. Variations in foreign exchange rate, changes in interest rates, and material price fluctuations have been considered to be important for contractors in developing countries (Ke et al. 2011; Chen, Lin 2010; Derakhshanalavijeh, Teixeira 2017).

Researchers have attempted to devise effective strategies to deal with financial risks. For example, Ling and Hoi (2006) identified several financial risk factors and appropriate tools for mitigating them. They asserted that risks associated with exchange rate and convertibility would be mitigated by having dual currency contracts where a portion can be paid with foreign currency while the other is domestic. They argued that hedging tools also can be used as a solution for profit repatriation. Likewise, Borgonovo and Peccati (2006) found that the risks of varying selling price of a commodity could be minimised using hedging techniques. Kaeck (2013) and Deng and Oren (2006) noted that

Table 1. Common hedging techniques (Hofmann 2011; Anderson et al. 2007; Brookes et al. 2000; Duangploy, Helmi 2000; Fatemi, Glaum 2000)

\begin{tabular}{ll}
\hline Technique & Description \\
\hline Forward contracts & $\begin{array}{l}\text { Contracting today to buy or sell a foreign currency at a future date at an ex- } \\
\text { change rate agreed today. }\end{array}$ \\
Futures contracts & $\begin{array}{l}\text { Futures contracts allow participants to buy or sell on a public exchange where } \\
\text { they trade with detailed knowledge of the contract. }\end{array}$ \\
An exchange of liabilities denominated in different currencies involving two par- \\
ties who agree to exchange specific amounts of different currencies at the outset
\end{tabular}


financial derivatives are beneficial in controlling undesired risks through properly structured hedging strategies. Huffman (2002) identified hedging as an effective strategy for financial risk, liquidity risk and foreign currency risk. Considering the price escalations of construction materials in Taiwan, Chen et al. (2012) developed a model to mitigate financial risks for construction work in markets experiencing high rates of inflation. Hedging for the present study has been considered as "taking positions that lower the risk profile of a portfolio" (Jorion 2009: 297). The most common hedging techniques that could be used in construction business are summarised in Table 1 .

\section{RESEARCH METHODS}

The primary method for conducting the present study followed a qual $\rightarrow Q U A N$ sequence as a category of mixed methods research (Johnson, Onwuegbuzie 2004). The mixed methods approach is one of the most effectual methods for conducting research in various areas of management through combining qualitative and quantitative methods. The application of mixed methods has been widely recommended by researchers in the construction context. According to Amaratunga et al. (2002), mixed methods research yields richer and deeper insights and overcomes the weaknesses of using a single method for doing research in the construction management field. Due to the novelty of the topic in the context of the study and the lack of prior investigation on the subject, conducting a qualitative approach as the first phase of a mixed methods research is recommended (Amaratunga et al. 2002). Hence, qual $\rightarrow Q U A N$ was selected in which 'a qualitative mini-study' was conducted to initiate and inform the leading approach (i.e. the quantitative one) as recommended by Johnson and Onwuegbuzie (2004). Conducting a qualitative mini study as the first stage of a mixed methods study enables researchers of discovering additional factors beyond those found in the existing literature and customises the information collated from the literature for the specific context of the study (Ijasan, Ahmed 2016). A common method for qualitative studies in construction research is conducting interviews (Amaratunga et al. 2002) as described next.

\subsection{Interviews}

Three preliminary interviews were carried out to complement, contextualise and customise the findings of review of literature through incorporating the perceptions of experts within the Sri Lankan context. To select the interviewees, the "purposive sampling" strategy was used, with this referring to "...sampling in a deliberate way, with some purposes or focus in mind" (Punch 2005: 187). The ultimate list of interviewees was finalised owing to the willingness of experts to take part in the interviews. Implementing this approach enhanced the richness of data due to the strong motivation of interviewees to contribute to the research. That is, in using purposive sampling to obtain qualitative data, respondents should be experts who have a special insight into the topic and, at the same time, are genuinely interested and committed to contributing to the study. This sampling strategy leads to identifying individuals who are very open and the most interested in the topic (Robinson 2014). As shown in Table 2, this resulted in having three practitioners as the interviewees with experience in financial risks and with extensive involvement in dealing with financial risks in the Sri Lankan construction context. As the interviews were seen as a part of a qualitative mini study to complement the literature and inform the quantitative phase, having three interviewees based on purposive sampling criteria was deemed adequate. Even more, as argued by Perera et al. (2016), the number of interviewees in such qualitative mini studies is irrelevant because the value of the study comes from the final quality of data collated from the literature and enhanced through the interviews.

Items identified through the literature review (financial risks and significant hedging techniques to manage such risks) were presented to the interviewees. The interviewees were asked to comment on whether these risks and hedging techniques were within the scope of the Sri Lankan construction contractors. They had to expound on their statements and provide reasons and examples to support their views. The interviews lasted 45-60 minutes and the proceedings were transcribed at the end using Cognitive Mapping technique to generalise the views of the three interviewees.

Table 2. Interview participants

\begin{tabular}{llll}
\hline ID & $\begin{array}{l}\text { Experience } \\
\text { (in years) }\end{array}$ & Role & Organisation \\
\hline Interviewee 1 & 24 years & $\begin{array}{l}\text { Contracts } \\
\text { manager }\end{array}$ & $\begin{array}{l}\text { Grade C1 } \\
\text { construction } \\
\text { contractor }\end{array}$ \\
Interviewee 2 & 20 years & $\begin{array}{l}\text { Chief } \\
\text { quantity } \\
\text { surveyor } \\
\text { Financial } \\
\text { controller }\end{array}$ & $\begin{array}{l}\text { Grade C1 } \\
\text { construction } \\
\text { contractor } \\
\text { Grade C1 } \\
\text { construction } \\
\text { contractor }\end{array}$ \\
\hline
\end{tabular}


The outcome of the literature review and interviews were aggregated to construct a framework for the study. This resulted in identifying the major financial risks applicable to contractors in Sri Lanka alongside the potential hedging techniques to counter them as captured in Table 3. It should be noted that all six common hedging techniques extracted from the literature were corroborated through the interviews as having a potential for countering the financial risks.

Table 3. Major financial risks and hedging techniques for Sri Lanka

\begin{tabular}{ll}
\hline $\begin{array}{l}\text { Major financial risks facing } \\
\text { contractors }\end{array}$ & $\begin{array}{l}\text { Commonplace hedging } \\
\text { techniques }\end{array}$ \\
\hline Variations in material prices & Forward contracts \\
Interest rate fluctuations & Futures contracts \\
Material shortages & Options contracts \\
Exchange rate fluctuations & Swaps contracts \\
& Structural or balance \\
& sheet hedges \\
& Invoicing in local currency \\
\hline
\end{tabular}

Nonetheless, the priority of the identified risks in terms of severity and the relative effectiveness of available hedging techniques had to be established in a systematic way to render the resource allocations efficient and optimised. This is suggestive of a prioritise the objectives, sub-objectives, and alternatives problem for which an effective solution is the Analytical Hierarchy Process (AHP) (Forman, Selly 2001; Yazdani-Chamzini et al. 2014).

\subsection{AHP}

The AHP is a multi-criteria decision analysis method that has been employed across various disciplines (Ishizaka, Labib 2011) to analyse a wide range of complicated problems in engineering management studies (Yazdani-Chamzini et al. 2014). An example of this is the construction industry (Vidal et al. 2011), particularly for making decisions concerning risks in many seminal studies (Hosseini et al. 2016) given the advantages provided by AHP for making decisions with regard to complicated problems (Yazdani-Chamzini et al. 2014). Apart from its widespread acceptance in academia, AHP does not require a large sample size (Duke, Aull-Hyde 2002). As a result, AHP was deemed an effective method for analysing the data in this study. There are around 15 different approaches for performing AHP which are delineated based on the selected alternative for completing each main stage of AHP (Ishizaka, Labib 2011). The following sub-sections describe the selected method for fulfilling three central stages of AHP in this study.

The first stage of AHP is to deconstruct the problem into a hierarchy consisting of major elements categorised into different layers, these being goals, objectives/sub-objectives, and alternatives (Forman, Selly 2001). For this study, the model illustrated in Figure 1 breaks the problem down into a 3-layer AHP model. The constructed model conforms to the principles introduced for arranging the clusters symmetrically as described by Ishizaka and Labib (2011). Because AHP models have some objectives that consist of more alternatives, this makes them prone to more errors in distributing the weights. At this stage, a set of pairwise comparisons should be constructed in which elements in any level are compared against each other with respect to the elements in the immediate upper level. In this study, elements in layer 2 (financial risks) were compared in terms of their severity for the upper level (level 1 i.e. the goal of managing the financial risks effectively). In the same vein, hedging techniques in layer 3 were compared against each other with respect to their suitability for dealing with each risk in layer 2 . The maximum number of elements were in level 3 (i.e. 6 alternatives), hence the use of absolute numbers for making comparisons were justified based on a 1-9 scale as recommended by Saaty (2008). The method selected for extracting the priorities out of each comparison matrix was the well-known one developed by Saaty (1977) according to which the principle eigenvector was used as a tenable and popular measure for calculating the vector of priorities. Likewise, the three-step mean of row approach was deployed to calculate the vector of priorities by considering Equation 1 as described by Ishizaka and Labib (2011):

$$
A \times P=\lambda \times P .
$$

In Equation 1, A represents the comparison matrix while $\lambda$ is the maximal eigenvalue and $P$ is the desired priorities vector. The maximum acceptable consistency ratio (CR) for each comparison matrix was considered to be $10 \%$ (Ishizaka, Labib 2011). For any CR greater than $10 \%$, the pair-wise comparison needs to be repeated in order to keep inconsistency to a minimum (Kildienè et al. 2014). It should be mentioned that AHP is not a method based on statistical techniques (Duke, Aull-Hyde 2002). Besides, "consistency in rating alternatives is rarely the case when subjectivity is involved" in AHP, thus CR is the most common measure 


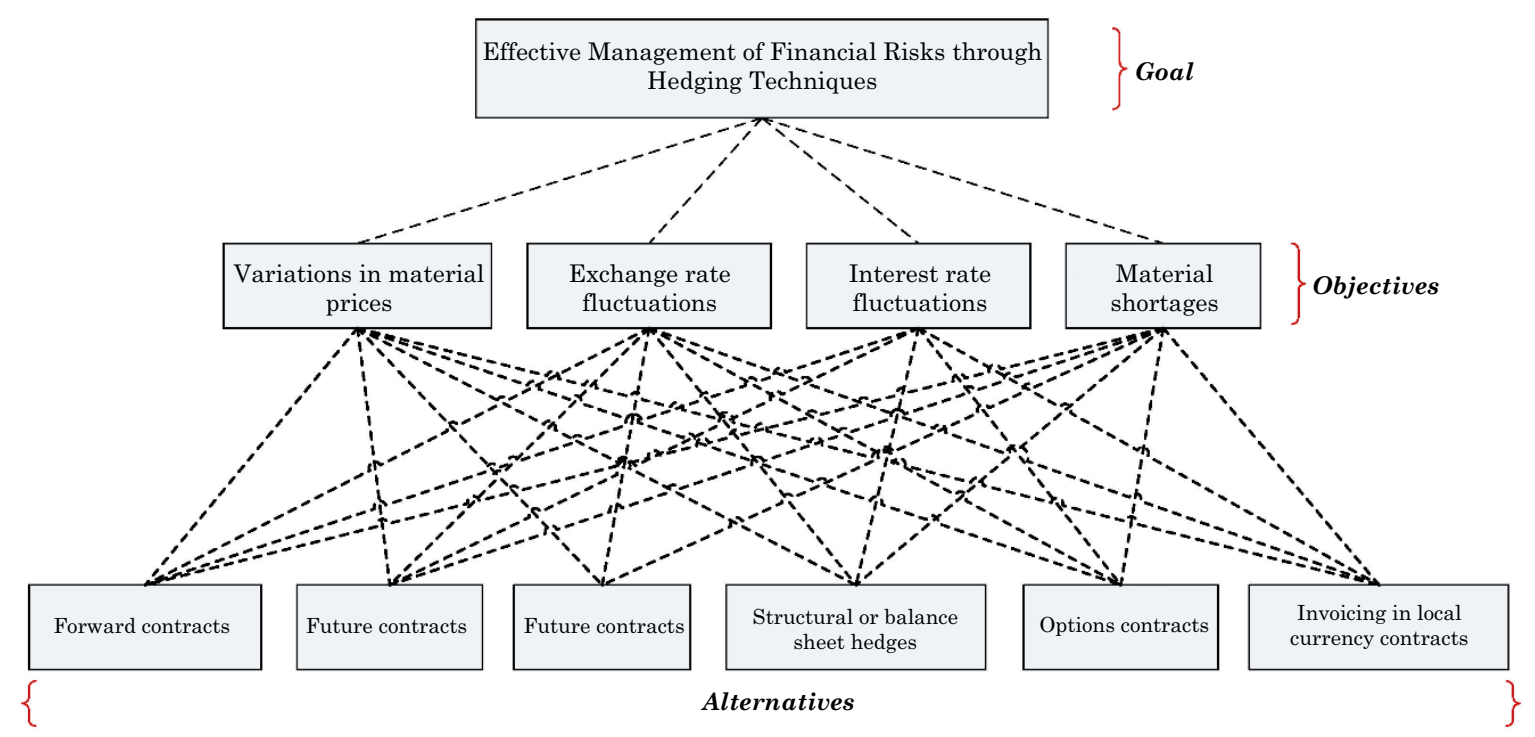

Fig. 1. The AHP model to deconstruct the problem in a hierarchy

to identify inconsistency among the respondents' rates (Duke, Aull-Hyde 2002: 136). The CR was calculated for each comparison matrix based on the responses of experts.

Generally, there are two methods to aggregate the judgments of respondents to achieve the results in a group-based AHP. These methods comprise the Aggregation of Individuals Judgments (AIJ) or the Aggregation of Individuals Priorities (AIP). Since the objective is to reach a response based on the consensus of the group, the AIP approach was performed as recommended by Forman and Peniwati (1998). Likewise, the final priority vectors in each case were calculated by considering Equation 2 using the geometric mean of individuals' priority vectors following Forman and Peniwati (1998) and Ishizaka and Labib (2011).

$$
P_{g}\left(A_{j}\right)=\prod_{i=1}^{33} P_{i}\left(A_{j}\right)^{w_{i}}
$$

In Equation 2, $P_{g}\left(A_{j}\right)$ represents the priority identified based on the group of experts' decision for alternative $j$ while $P_{i}\left(A_{j}\right)$ refers to each individual $i$ 's priority of alternative $j$. It should be noted that $w_{i}$ is applicable to cases in which different individuals have different weights in decisionmaking. In such cases, $w_{i}$ represents the weight of individual $i$ that in this study was assumed equal for all the respondents.

\subsection{Data collection}

To collect data, a questionnaire survey was conducted targeting the financial decision-makers of lead- ing Sri Lankan contractors with a C1-C4 grading in construction work headquartered in Colombo (Institute for Construction Training and Development 2008). As such, the sampling method followed the principles of purposive sampling which "is typically designed to pick a small number of cases that will yield the most information about a particular phenomenon" (Teddlie, Yu 2007: 83). Compared against probability sampling with a large sample size, purposive sampling leads to a greater depth of knowledge from a small number of experts on the topic (Teddlie, Yu 2007). Moreover, AHP as the primary analysis method of the present study is not statistically-based, thus even "a 'sample size' of 1 is enough to implement the AHP methodology" as articulated by Duke and Aull-Hyde (2002: 134). AHP is utilised to use a small group of experts to define a specific problem based on these experts 'own experience. Deploying groups as small as five to twelve experts are typical of AHP studies (Duke, Aull-Hyde 2002). Therefore, to elicit the perceptions of these experts on the usefulness of hedging techniques, 97 requests were sent out. These 97 experts were identified by the respective contractor organisations as involved in financial decision-making of the firm or project sites. Eventually, 33 duly completed and returned questionnaires formed the basis of the primary data for this study. The response rate was $34 \%$ while response rates around $10 \%$ are not untypical of contemporary construction management research (Bing et al. 2005). In view of the above facts, the sample size and the response rate of the present study were deemed acceptable. Table 4 illustrates the professional background of the respondents. 
Table 4. Background of questionnaire respondents

\begin{tabular}{llll}
\hline Position of respondents & Number & $\begin{array}{l}\text { Length of service in } \\
\text { the industry }\end{array}$ & Organisation \\
\hline Quantity surveyor/commercial manager & 12 & More than 10 years & Construction contractor \\
Contracts manager & 5 & More than 10 years & Construction contractor \\
Financial controller/accountant & 5 & More than 10 years & Construction contractor \\
Project manager/project engineer/coordinator & 11 & More than 10 years & Construction contractor \\
\hline Total & 33 & - & - \\
\hline
\end{tabular}

\section{RESULTS}

\subsection{Major financial risks}

The first section of the questionnaire was aimed at eliciting perceptions from experts with respect to the severity of financial risks facing construction contractors in Sri Lanka. The second part encompassed prioritising the hedging techniques based on their perceived suitability in dealing with the identified financial risks. Table 5 illustrates the priority vector gained from comparing alternatives with respect to the goal of the model. The consistency ratios (CR) for each respondent's matrix were calculated of which the maximum was 0.102 , which was deemed reliable based on the allowable consistency ratio (0.10) as described.

Table 5. Aggregated priorities and ranks of financial risks

\begin{tabular}{ll}
\hline Financial risk factor & $\begin{array}{l}\text { Aggregated priorities } \\
\text { (rank) }\end{array}$ \\
\hline Variations in material prices & $0.416(1)$ \\
Interest rate fluctuations & $0.278(2)$ \\
Material shortages & $0.223(3)$ \\
Exchange rate fluctuations & $0.084(4)$ \\
\hline
\end{tabular}

\subsection{Effective hedging techniques}

The next stage of the questionnaire entailed assessing the suitability of hedging techniques in countering the four risk factors (i.e. extracting the priority vector associated with level 3 with respect to level 2 of the model in Figure 1) as identified and illustrated in Table 5. The priorities extracted from the aggregated results of the AHP analysis are illustrated in Table 6.
The overall perceived suitability of hedging techniques i.e. the global priorities of AHP model are captured in Table 7.

Table 7. The global priorities and ranks of hedging techniques

\begin{tabular}{lll}
\hline Hedging techniques & $\begin{array}{l}\text { Overall } \\
\text { priorities }\end{array}$ & Ranking \\
\hline Forward contracts & 0.396 & 1 \\
Futures contracts & 0.181 & 2 \\
Options contracts & 0.142 & 3 \\
Structural or balance & 0.123 & 4 \\
sheet hedges & & \\
$\begin{array}{l}\text { Swaps contracts } \\
\text { Invoicing in local }\end{array}$ & 0.121 & 5 \\
currency & 0.038 & 6 \\
\hline
\end{tabular}

\section{DISCUSSIONS}

Findings of the study could be summarised as the model illustrated in Figure 2. As for the most important financial risks, the findings in Figure 2 demonstrate a consistency with observations in other developing countries. That is, according to Ghahramanzadeh (2013: 100), for Iranian clients on construction projects "the first three risks in terms of criticality are cost overrun, foreign exchange and convertibility, and inflation and interest rate". As shown in Table 5, the highest important score has been secured by the financial risk arising from variations in material prices. It is understandable as market instability is a rampant issue in developing countries (Beck et al. 2010; Iqbal et al. 2015). Heavy reliance on imported materials

Table 6. Priority vectors reflecting the perceived suitability of hedging techniques in managing the identified financial risks

\begin{tabular}{lllll}
\hline Financial risk factor & VP & IF & MS & EF \\
& $(0.416)$ & $(0.278)$ & $(0.223)$ & $0.084)$ \\
\hline Forward contracts & 0.384 & 0.419 & 0.393 & 0.385 \\
Futures contracts & 0.170 & 0.187 & 0.176 & 0.231 \\
Swaps contracts & 0.069 & 0.154 & 0.168 & 0.145 \\
Options contracts & 0.158 & 0.111 & 0.163 & 0.103 \\
Structural or balance sheet hedges & 0.181 & 0.091 & 0.063 & 0.096 \\
Invoicing in local currency & 0.038 & 0.037 & 0.037 & 0.041 \\
\hline
\end{tabular}




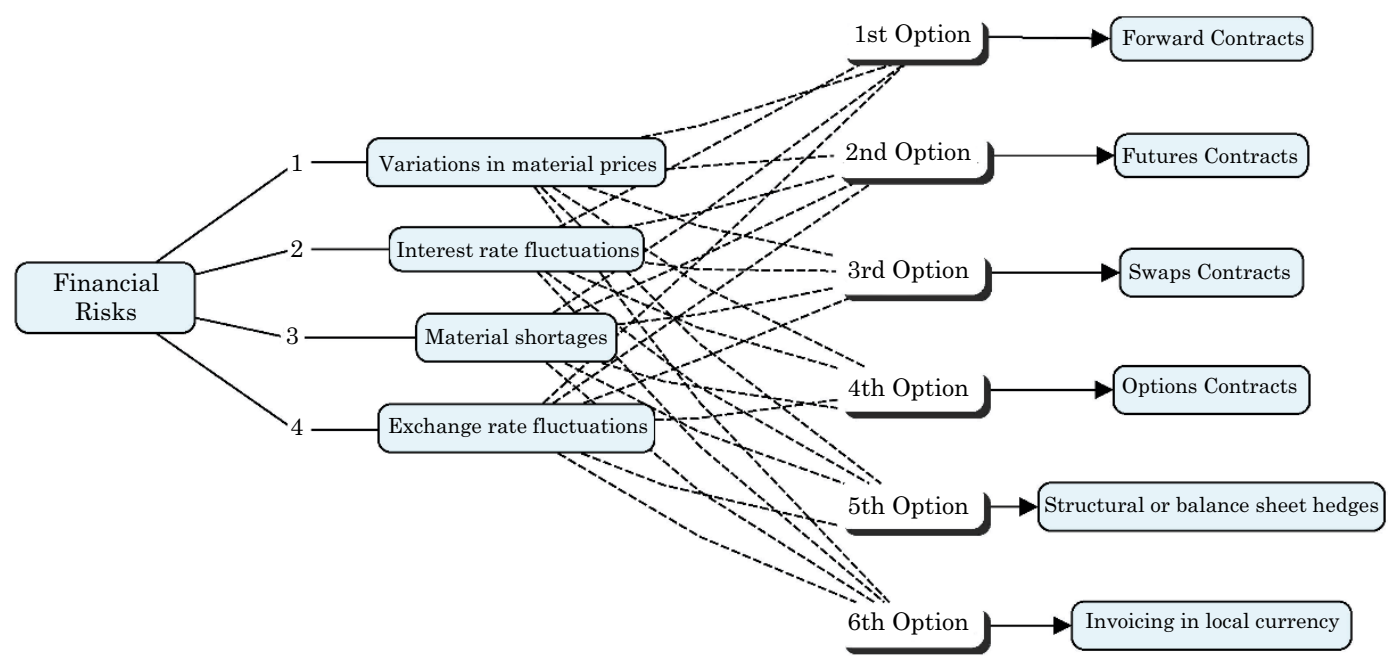

Fig. 2. Integrated model of financial risks and hedging techniques for developing countries

could also be a factor triggering the variances in material prices coupled with exchange rate fluctuations (Giang, Sui Pheng 2011). Material price fluctuations could also be attributed to inflation in developing countries as identified by Ghahramanzadeh (2013) for Iran. It could be linked to material shortages in the local market as asserted by Perera et al. (2014) for Sri Lanka. In the same vein, fluctuations of material prices were identified by Chan et al. (2011) as a critical risk factor for contractors in Hong Kong, which emphasises such detrimental effects even in countries that have been categorised as developed.

Interest rate fluctuations ranked as the second while material shortages and exchange rate fluctuations the third and the fourth respectively. The fluctuations in interest rate might affect many aspects of construction work, mainly the cost of borrowing which is at the heart of every contractor's cash flow (Maravas, Pantouvakis 2012). Shortage of materials is a serious issue in developing countries such as Palestine (Enshassi et al. 2009), Jordan (Sweis et al. 2008) and Nigeria (Okpala, Aniekwu 1988). Availability of materials was identified as a major obstacle for Egyptian contractors due to financial problems in a recent study by El-Gohary and Aziz (2014). The authors opined that materials shortage is a rampant issue for contractors in most developing countries. One possible operational remedy would be to purchase materials early in lieu of purchasing them at higher prices during the course of the contract. Stockpiling of steel and rebar prior to the Beijing Olympics was a typical example of this strategy. This would not be the case for contractors in many developing countries due to the endemic financial problems they encounter (Baloi, Price 2003) and a lack of financial strength (Ghoddousi, Hosseini 2012). Exchange rate fluctuations can have an impact on prices of imported materials and equipment as well as fuel, which comprise a very high proportion of the costs of constructed products in Sri Lanka (Central Bank of Sri Lanka 2012). According to the Board of Investment (BOI 2013) imported components used in a major infrastructure vary from $45-63 \%$ of the total cost.

Generally, the risks identified in Figure 2 seem to be tenable for a typical developing country such as Sri Lanka. The instability of the overall economy, currency fluctuations and changes in interest rates alongside shortage of materials emerged as the main causes of financial problems in developing countries (Baloi, Price 2003). This is exacerbated by the lack of financial facilities and the associated complex supply chains in such countries (El-Gohary, Aziz 2014). Literature acknowledges that most of the financial risks of contractors have roots in the local economic conditions (Zhi 1995). Due to this vicious cycle, in most cases contractors might not have sufficient collateral to obtain finances from commercial banks (Chiang, Cheng 2011).

In view of overcoming financial issues, construction companies in developing countries including Sri Lankan contractors normally resort to trade credit, accrued expenses and even differed payments as highlighted by Perera et al. (2014). In essence, one of the most pressing problems of small and medium scale contractors is obtaining the 'working capital' required for a project (Eyiah 2001). While trade credit, accrued expenses, differed payments, advance payment and construction 
guarantee fund are very useful for solving working capital issues, the overall financial risks are not well shielded by these measures. In that sense, the use of hedging techniques will bolster the efforts of contractors in developing countries to resolve some of the major challenges stemmed from financial risks as endorsed by the respondents of the study.

As far as the most suitable hedging techniques are concerned, using forward contracts was identified as the most influential technique, thus was considered the first option to deal with identified financial risks and ameliorating the detrimental effects of financial risks. This was consistent with the results of Chau et al. (2007) who introduced forward contracts as a popular method to relieve financial risks of contractors. As shown in Table 7, apart from forwards contracts technique that by far outperforms others, no glaring differences could be observed among the other four techniques. It should be noted that although the suitability of forward contracts in dealing with exchange rate fluctuations is well established in the construction literature, some concerns have risen about the quality of products of these contracts in the market (Chau et al. 2007). Structural or balance sheet hedges, futures contracts, swaps contracts, and options contracts are similar in their potential to manage financial risks and were ranked as the second to the fifth most influential hedging techniques for tackling identified financial risks. However, invoicing in local currency held a noticeably low priority and could be deemed ineffective in managing any financial risk associated with construction projects as illustrated in Figure 2. In general, it could be construed that there is no major difference between the suitability of most hedging techniques in dealing with various financial risks as inferred from Table 7 . In other words, contractors could use the same method for different financial risks. This assumption has been highlighted by Whaley (2006) stating that effective hedging techniques for currency exchange fluctuations are not different from those regarding interest rate fluctuations.

\section{CONCLUSION}

The findings of the present study go beyond the boundaries of the existing body of the knowledge on financial risks and hedging techniques by (1) customising and contextualising the most important financial risks within the natural context of Sri Lanka, (2) investigating the most effective hedging techniques in view of the nature of com- mon financial risks for Sri Lanka and (3) presenting an integrated model to outline the most important financial risks and the most effective hedging techniques to deal with each risk. In practical terms, the findings direct contractors and policy makers towards focusing their effort and allocating the resources in dealing with the issues of four major risks as identified in the present study. The results would provide an insight for construction practitioners in any country with high levels of financial uncertainty in the industry and at project level. The finding would be of particular interest for Sri Lanka but might be valuable for practitioners in other developing countries in which implementing risk management initiatives and hedging techniques might not be a common practice. Operational remedies such as purchasing materials and products within the initial stages of project lifecycle would not be viable due to the financial weaknesses of contractors in Sri Lanka. Yet, the findings revealed that a hedging technique such as forward contracts is typically effective in easing the adverse effects of different financial risks. As a result, implementing forward contracts could be regarded as a remedy for dealing with a wide range of financial risks adversely affecting contractors in Sri Lanka.

Despite the valuable findings and consistency with previous studies, the findings of the study reflect the perceptions of a selected group of experts who are responsible for making financial decisions in contractor organisations in Sri Lanka. While the perceptions are useful in understanding and categorising the critical risk factors and suitable remedies, the fact that the sample comes only from a small group of experts in one country must be taken into account in applying the findings in other contexts. Another limitation of the study is due to its explicit focus on hedging. The abilities of hedging as an effective financial risk management method has been acknowledged in the literature, yet hedging might not be the only or the best method for dealing with financial risks. Even more, experts in Sri Lanka identified four financial risks as the most important ones. Practitioners intending to utilise the findings in contexts different from Sri Lanka should incorporate the impacts of particular socio-economic conditions on defining the risks for each country. Such limitations direct future investigations of these issues to bolster financial risk related research in developing countries. This includes, validating the findings of the study in other developing countries alongside investigating the most effective methods to deal with financial 
risks for unstable and volatile economies. Even more, the importance of financial risks for such countries, opens up a range of potential topics for further research. This includes investigating the current practices, barriers, and drivers associated with implementing risk management initiatives for dealing with financial risks and particularly forward contracts in the construction industry of developing countries.

\section{REFERENCES}

Akintoye, A.; MacLeod, M. 1997. Risk analysis and management in construction, International Journal of Project Management 15(1): 31-38.

https://doi.org/10.1016/S0263-7863(96)00035-X

Amaratunga, D; Baldry, D.; Sarshar, M.; Newton, R. 2002. Quantitative and qualitative research in the built environment: application of "mixed" research approach, Work Study 51(1): 17-31.

https://doi.org/10.1108/00438020210415488

Anderson, E.; Hu, X.; Winchester, D. 2007. Forward contracts in electricity markets: the Australian experience, Energy Policy 35(5): 3089-3103.

https://doi.org/10.1016/j.enpol.2006.11.010

Baloi, D.; Price, A. 2003. Modelling global risk factors affecting construction cost performance, International Journal of Project Management 21(4): 261-269. https://doi.org/10.1016/S0263-7863(02)00017-0

Banaitienè, N.; Banaitis, A.; Norkus, A. 2011. Risk management in projects: peculiarities of Lithuanian construction companies, International Journal of Strategic Property Management 15(1): 60-73. https://doi.org/10.3846/1648715X.2011.568675

Battermann, H.; Broll, U. 2001. Inflation risk, hedging, and exports, Review of Development Economics 5(3): 355-362. https://doi.org/10.1111/1467-9361.00128

Beck, T.; Demirgüç-Kunt, A; Levine, R. 2010. Financial institutions and markets across countries and over time: the updated financial development and structure database, The World Bank Economic Review 24(1): 77-92. https://doi.org/10.1093/wber/lhp016

Bing, L.; Akintoye, A., Edwards, P.; Hardcastle, C.; 2005. The allocation of risk in PPP/PFI construction projects in the UK, International Journal of Project Management 23(1): 25-35.

https://doi.org/10.1016/j.ijproman.2004.04.006

BOI. 2013. Key sectors for investment - infrastructure [online]. Board of Investment of Sri Lanka. Available at: http://www.investsrilanka.com [accessed 1 December 2016].

Borgonovo, E.; Peccati, L. 2006. The importance of assumptions in investment evaluation, International Journal of Production Economics 101(2): 298-311. https://doi.org/10.1016/j.ijpe.2005.01.009

Brookes, A.; Hargreaves, D.; Lucas, C.; White, B. 2000. Can hedging insulate firms from exchange rate risk?, Reserve Bank of New Zealand Bulletin 63(1): 21-34.

Campello, M.; Lin, C.; Ma, Y.; Zou, H. 2011. The real and financial implications of corporate hedging, Journal of Finance 66(5): 1615-1647. https://doi.org/10.1111/j.1540-6261.2011.01683.x
Central Bank of Sri Lanka. 2012. Economic \& social statistics of Sri Lanka [online]. Available at: http:// www.cbsl.gov.lk [accessed 1 December 2016].

Ceric, A. 2014. Minimizing communication risk in construction: a Delphi study of the key role of project managers, Journal of Civil Engineering and Management 20(6): 829-838.

https://doi.org/10.3846/13923730.2013.802739

Chan, D.; Chan, A.; Lam, P.; Yeung, J.; Chan. 2011. Risk ranking and analysis in target cost contracts: empirical evidence from the construction industry, International Journal of Project Management 29(6): 751763. https://doi.org/10.1016/j.ijproman.2010.08.003

Chau, K.; Wong, S.; Yiu, C. 2007. Housing quality in the forward contracts market, Journal of Real Estate Finance and Economics 34(3): 313-325.

https://doi.org/10.1007/s11146-007-9018-x

Chen, J.; Hsu, S.; Luo, Y.; Skibniewski, M. 2012. Knowledge management for risk hedging by construction material suppliers, Journal of Management in Engineering 28(3): 273-280. https://doi.org/10.1061/ (ASCE)ME.1943-5479.0000111

Chen, J.; Lin, J. 2010. Developing an SVM based risk hedging prediction model for construction material suppliers, Automation in Construction 19(6): 702708. https://doi.org/10.1016/j.autcon.2010.02.014

Chen, J.; Yang, L.; Su, M.; Lin, J. 2010. A rule extraction based approach in predicting derivative use for financial risk hedging by construction companies, Expert Systems with Applications 37(9): 6510-6514. https://doi.org/10.1016/j.eswa.2010.02.135

Chiang, Y.; Cheng, E. 2011. Revealing bank lending decisions for contractors in Hong Kong, International Journal of Project Management 29(2): 137-145. https://doi.org/10.1016/j.ijproman.2010.02.003

Dai, J.; Goodrum, P.; Maloney, W.; Srinivasan, C. 2009. Latent structures of the factors affecting construction labor productivity, Journal of Construction Engineering and Management 135(5): 397-406. https:// doi.org/10.1061/(ASCE)0733-9364(2009)135:5(397)

Deng, S.; Oren, S. 2006. Electricity derivatives and risk management, Energy 31(6-7): 940-953. https://doi.org/10.1016/j.energy.2005.02.015

Derakhshanalavijeh, R.; Teixeira, J. 2017. Cost overrun in construction projects in developing countries, gas-oil industry of Iran as a case study, Journal of Civil Engineering and Management 23(1): 125-136. https://doi.org/10.3846/13923730.2014.992467

Duangploy, O.; Helmi, D. 2000. Foreign currency hedge accounting: multi-currency versus functional currency accounting, Managerial Auditing Journal 15(5): 232-246. https://doi.org/10.1108/02686900010339364

Duke, J.; Aull-Hyde, R. 2002. Identifying public preferences for land preservation using the analytic hierarchy process, Ecological Economics 42(1-2): 131-145. https://doi.org/10.1016/S0921-8009(02)00053-8

El-Gohary, K.; Aziz, R. 2014. Factors influencing construction labor productivity in Egypt, Journal of Management in Engineering 30(1): 1-9. https://doi. org/10.1061/(ASCE)ME.1943-5479.0000168

Enshassi, A.; Mohamed, S.; Abushaban, S. 2009. Factors affecting the performance of construction projects in the Gaza Strip, Journal of Civil Engineer- 
ing and Management 15(3): 269-280. https://doi. org/10.3846/1392-3730.2009.15.269-280

Eyiah, A. 2001. An integrated approach to financing small contractors in developing countries: a conceptual model, Construction Management and Economics 19(5): 511-518. https://doi.org/10.1080/01446193. 2001.9709627

Fatemi, A.; Glaum, M. 2000. Risk management practices of German firms, Managerial Finance 26(3): 1-17. https://doi.org/10.1108/03074350010766549

Ferguson, M.; Overdahl, J.; Qiu, B. 2012. Corporate hedging and financial contracting [online]. Available at SSRN: https://ssrn.com/abstract $=1844699$ [accessed 1 December 2016]

https://doi.org/10.2139/ssrn.1844699

Forman, E; Selly, M. 2001. Decision by objectives: how to convince others that you are right. River Edge, N.J.: World Scientific Publishing Co. https://doi.org/10.1142/4281

Forman, E.; Peniwati, K. 1998. Aggregating individual judgments and priorities with the analytic hierarchy process, European Journal of Operational Research 108(1): 165-169.

https://doi.org/10.1016/S0377-2217(97)00244-0

Ghahramanzadeh, M. 2013. Managing risk of construction projects: a case study of Iran: Unpublished PhD. University of East London.

Ghoddousi, P.; Hosseini, M. 2012. A survey of the factors affecting the productivity of construction projects in Iran, Technological and Economic Development of Economy 18(1): 99-116. https://doi.org/10.3846/20294913.2012.661203

Giang, D.; Pheng, L. 2011. Role of construction in economic development: review of key concepts in the past 40 years, Habitat International 35(1): 118-125. https://doi.org/10.1016/j.habitatint.2010.06.003

Ginevičius, R.; Podvezko, V. 2006. Assessing the financial state of construction enterprises, Technological and Economic Development of Economy 12(3): 188-194.

Goh, C.; Abdul-Rahman, H. 2013. The identification and management of major risks in the Malaysian construction industry, Journal of Construction in Developing Countries 18(1): 19-32.

Hammoudeh, S.; Yuan, Y.; Chiang, T.; Nandha, M. 2010. Symmetric and asymmetric US sector return volatilities in presence of oil, financial and economic risks, Energy Policy 38(8): 3922-3932. https://doi.org/10.1016/j.enpol.2010.03.015

Hlaing, N.; Singh, D.; Tiong, R.; Ehrlich, M. 2008. Perceptions of Singapore construction contractors on construction risk identification, Journal of Financial Management of Property and Construction 13(2): 8595. https://doi.org/10.1108/13664380810898104

Hofmann, E. 2011. Natural hedging as a risk prophylaxis and supplier financing instrument in automotive supply chains, Supply Chain Management: An International Journal 16(2): 128-141. https://doi.org/10.1108/13598541111115374

Hosseini, M.; Chileshe, N.; Jepson, J.; Arashpour, M. 2016. Critical success factors for implementing risk management systems in developing countries,
Construction Economics and Building 16(1): 18-32. https://doi.org/10.5130/AJCEB.v16i1.4651

Hosseini, S.; Arefi, S.; Bitarafan, M.; Abazarlou, S.; Zavadskas, E. K. 2016. Evaluation types of exterior walls to reconstruct Iran earthquake areas (Ahar Heris Varzeqan) by using AHP and fuzzy methods, International Journal of Strategic Property Management 20(3): 328-340. https://doi.org/10.3846/1648715X.2016.1190794

Huffman, F. 2002. Corporate real estate risk management and assessment, Journal of Corporate Real Estate 5(1): 31-41.

https://doi.org/10.1108/14630010310811984

Hwang, B.; Zhao, X.; Toh, L. 2013. Risk management in small construction projects in Singapore: status, barriers and impact, International Journal of Project Management 32(1): 116-124.

https://doi.org/10.1016/j.ijproman.2013.01.007

Ijasan, K.; Ahmed, V. 2016. Studentification and the housing needs of international students in Johannesburg: an embedded mixed methods approach, in Ahmed, V.; Opoku, A.; Aziz, Z. (Eds.), Research methodology in the built environment: a selection of case studies. London: Routledge.

Institute for Construction Training and Development. 2008. Sri Lanka country report, in $14^{\text {th }} A S I A C O N$ STRUCT Conference, 23-24 October 2008, Tokyo, Japan [online]. Available at: http://www.asiaconst.com/ past_conference/conference/14th/07Sri\%20Lanka.pdf [accessed 1 December 2016]

Iqbal, S.; Choudhry, R.; Holschemacher, K.; Ali, A.; Tamošaitienè, J. 2015. Risk management in construction projects, Technological and Economic Development of Economy 21(1): 65-78.

https://doi.org/10.3846/20294913.2014.994582

Ishizaka, A.; Labib, A. 2011. Review of the main developments in the analytic hierarchy process, Expert Systems with Applications 38(11): 14336-14345. https://doi.org/10.1016/j.eswa.2011.04.143

Jiang, H.; Liu, C. 2015. Identifying determinants of demand for construction using an econometric approach, International Journal of Strategic Property Management 19(4): 346-357. https://doi.org/10.3846/1648715X.2015.1072856

Johnson, R.; Onwuegbuzie, A. 2004. Mixed methods research: a research paradigm whose time has come, Educational Researcher 33(7): 14-26. https://doi.org/10.3102/0013189X033007014

Jorion, P. 2009. Financial risk manager handbook. $5^{\text {th }}$ ed. Hoboken, N.J.: Wiley.

Kaeck, A. 2013. Hedging surprises, jumps, and model misspecification: a risk management perspective on hedging S\&P 500 options*, Review of Finance 17(4): 1535-1569. https://doi.org/10.1093/rof/rfs027

Kartam, N.; Kartam, S. 2001. Risk and its management in the Kuwaiti construction industry: a contractors' perspective, International Journal of Project Management 19(6): 325-335.

https://doi.org/10.1016/S0263-7863(00)00014-4

Ke, Y.; Wang, S.; Chan, A.; Cheung, E. 2011. Understanding the risks in China's PPP projects: ranking of their probability and consequence, Engineering, 
Construction and Architectural Management 18(5): 481-496. https://doi.org/10.1108/09699981111165176

Kildienè, S.; Zavadskas, E.; Tamošaitienè, J. 2014. Complex assessment model for advanced technology deployment, Journal of Civil Engineering and Management 20(2): 280-290.

https://doi.org/10.3846/13923730.2014.904813

Le-Hoai, L.; Lee, Y.; Lee, J. 2008. Delay and cost overruns in Vietnam large construction projects: a comparison with other selected countries, KSCE Journal of Civil Engineering 12(6): 367-377.

https://doi.org/10.1007/s12205-008-0367-7

Li, H.; Arditi, D.; Wang, Z. 2015. Determinants of transaction costs in construction projects, Journal of Civil Engineering and Management 21(5): 548-558. https://doi.org/10.3846/13923730.2014.897973

Ling, F.; Hoi, L. 2006. Risks faced by Singapore firms when undertaking construction projects in India, International Journal of Project Management 24(3): 261-270.

https://doi.org/10.1016/j.ijproman.2005.11.003

Mansfield, N.; Ugwu, R.; Doran, T. 1994. Causes of delay and cost overruns in Nigerian construction projects, International Journal of Project Management 12(4): 254-260.

https://doi.org/10.1016/0263-7863(94)90050-7

Maravas, A.; Pantouvakis, J. 2012. Project cash flow analysis in the presence of uncertainty in activity duration and cost, International Journal of Project Management 30(3): 374-384.

https://doi.org/10.1016/j.ijproman.2011.08.005

Okpala, D.; Aniekwu, A. 1988. Causes of high costs of construction in Nigeria, Journal of Construction Engineering and Management 114(2): 233-244. https:// doi.org/10.1061/(ASCE)0733-9364(1988)114:2(233)

Olawale, Y.; Sun, M. 2010. Cost and time control of construction projects: inhibiting factors and mitigating measures in practice, Construction Management and Economics 28(5): 509-526.

https://doi.org/10.1080/01446191003674519

Perera, B.; Rameezdeen, R.; Chileshe, N.; Hosseini, M. 2014. Enhancing the effectiveness of risk management practices in Sri Lankan road construction projects: a Delphi approach, International Journal of Construction Management 14(1): 1-19.

https://doi.org/10.1080/15623599.2013.875271

Perera, B.; Ahamed, A.; Rameezdeen, R.; Chileshe, N.; Hosseini, M. 2016. Provision of facilities management services in Sri Lankan commercial organisations: is in-house involvement necessary?, Facilities 34(7/8): 394-412. https://doi.org/10.1108/F-12-2014-0102

Perera, B.; Dhanasinghe, I.; Rameezdeen, R. 2009. Risk management in road construction: the case of Sri Lanka, International Journal of Strategic Property Management 13(2): 87-102.

https://doi.org/10.3846/1648-715X.2009.13.87-102

Piyadasa, W.; Hadikusumo, B. 2014. Risk assessment in non-standard forms of civil engineering consulting services, Journal of Civil Engineering and Management 20(5): 746-759.

https://doi.org/10.3846/13923730.2013.801912
Punch, K. 2005. Introduction to social research: quantitative and qualitative approaches. Thousand Oaks: Sage Publications Ltd.

Robinson, O. 2014. Sampling in interview-based qualitative research: a theoretical and practical guide, Qualitative Research in Psychology 11(1): 25-41. https://doi.org/10.1080/14780887.2013.801543

Ruddock, L.; Amaratunga, D.; Wanigaratne, N.; Palliyaguru, R. 2010. Post-tsunami reconstruction in Sri Lanka: assessing the economic impact, International Journal of Strategic Property Management 14(3): 217-230. https://doi.org/10.3846/ijspm.2010.16

Saaty, T. 2008. Decision making with the analytic hierarchy process, International Journal of Services Sciences 1(1): 83-98.

Saaty, T. 1977. A scaling method for priorities in hierarchical structures, Journal of Mathematical Psychology 15(3): 234-281.

https://doi.org/10.1016/0022-2496(77)90033-5

Shevchenko, G.; Ustinovichius, L.; Andruškevičius, A. 2008. Multi-attribute analysis of investments risk alternatives in construction, Technological and Economic Development of Economy 14(3): 428-443. https://doi.org/10.3846/1392-8619.2008.14.428-443

Sweis, G.; Sweis, R.; Abu Hammad, A.; Shboul, A. 2008. Delays in construction projects: the case of Jordan, International Journal of Project Management 26(6): 665-674.

https://doi.org/10.1016/j.ijproman.2007.09.009

Tadayon, M.; Jaafar, M.; Nasri, E. 2012. An assessment of risk identification in large construction projects in Iran, Journal of Construction in Developing Countries 17(1): 57-69.

Tah, J.; Carr, V. 2000. A proposal for construction project risk assessment using fuzzy logic, Construction Management and Economics 18(4): 491-500. https://doi.org/10.1080/01446190050024905

Teddlie, C.; Yu, F. 2007. Mixed methods sampling: a typology with examples, Journal of Mixed Methods Research 1(1): 77-100.

https://doi.org/10.1177/2345678906292430

Turskis, Z.; Gajzler, M.; Dziadosz, A. 2012. Reliability, risk management, and contingency of construction processes and projects, Journal of Civil Engineering and Management 18(2): 290-298.

https://doi.org/10.3846/13923730.2012.672931

Vidal, L.; Marle, F.; Bocquet, J. 2011. Measuring project complexity using the Analytic Hierarchy Process, International Journal of Project Management 29(6): 718-727.

https://doi.org/10.1016/j.ijproman.2010.07.005

Whaley, R. 2006. Derivatives: markets, valuation, and risk management. Hoboken, N.J.: Wiley.

Yalegama, S.; Chileshe, N.; Ma, T. 2016. Critical success factors for community-driven development projects: a Sri Lankan community perspective, International Journal of Project Management 34(4): 643-659. https://doi.org/10.1016/j.ijproman.2016.02.006

Yazdani-Chamzini, A.; Shariati, S.; Haji Yakhchali, S.; Zavadskas, E. K. 2014. Proposing a new methodology for prioritising the investment strategies in the 
private sector of Iran, Economic Research-Ekonomska Istraživanja 27(1): 320-345.

https://doi.org/10.1080/1331677X.2014.947150

Zavadskas, E. K.; Turskis, Z.; Bagočius, V. 2015. Multicriteria selection of a deep-water port in the Eastern Baltic Sea, Applied Soft Computing 26: 180-192. https://doi.org/10.1016/j.asoc.2014.09.019

Zavadskas, E. K.; Turskis, Z.; Tamošaitiene, J. 2010a. Risk assessment of construction projects, Journal of Civil Engineering and Management 16(1): 33-46. https://doi.org/10.3846/jcem.2010.03
Zavadskas, E.; Vilutiene, T.; Turskis, Z.; Tamosaitiene, J. 2010b. Contractor selection for construction works by applying SAW-G and TOPSIS grey techniques, Journal of Business Economics and Management 11(1): 34-55. https://doi.org/10.3846/jbem.2010.03

Zhi, H. 1995. Risk management for overseas construction projects, International Journal of Project Management 13(4): 231-237. https://doi.org/10.1016/0263-7863(95)00015-I

Zou, P.; Zhang, G.; Wang, J. 2007. Understanding the key risks in construction projects in China, International Journal of Project Management 25(6): 601614. https://doi.org/10.1016/j.ijproman.2007.03.001 